\title{
Attenuation capacity of soil mixed with palm oil fuel ash (POFA) liner for treating leachate
}

\begin{abstract}
This paper presents the results of a study on the effectiveness of mixtures of granite residual soil with palm oil fuel ash (POFA) to attenuate leachate contaminants. Granite residual soil samples were mixed with 0 to $15 \%$ POFA. A short term filtration processes and hydraulic conductivity test were conducted simultaneously using a falling head apparatus with natural leachate as the permeant. The values of natural attenuation capacity of the compacted soil mixed with various percentage of POFA were determine by carrying out several water quality tests on the influent and effluent. The parameters measured were Total Suspended Solids (TSS), Biochemical Oxygen Demand (BOD), Chemical Oxygen Demand (COD) values and some selected heavy metal (Chromium, Copper, Manganese, Lead and Zinc). The results showed the highest reduction in hydraulic conductivity $(65.4 \%)$ was achieved by the compacted soil mixed with 10\% POFA. The removal rate of all parameters studied except for copper increased with the increment of POFA content.
\end{abstract}

Keyword: Attenuation; Leachate; Residual soil; Palm oil fuel ash 